\title{
PCR typing of Corynebacterium diphtheriae by random amplification of polymorphic DNA
}

\author{
A. S. DE ZOYSA and A. EFSTRATIOU \\ Respiratory and Systemic Infection Laboratory, PHLS Central Public Health Laboratory, 61 Colindale Avenue, \\ London NW9 5 HT
}

\begin{abstract}
The usefulness of random amplification of polymorphic DNA (RAPD) analysis with Ready-To-Go ${ }^{\circledR}$ RAPD beads was investigated for the rapid differentiation of Corynebacterium diphtheriae isolates from Eastern Europe and neighbouring countries. A selection of $45 C$. diphtheriae isolates of known origin, biotype, toxigenicity status and ribotype were examined by RAPD. Twenty RAPD profiles (designated Rp1-Rp20) were revealed among the 45 isolates. There was $100 \%$ correlation between RAPD profiles and ribotypes. Preliminary studies showed that the use of crude DNA preparations resulted in poor amplification and the patterns were not reproducible. Different thermal cycler models produced different RAPD profiles from the same DNA sample. Reproducibility of the technique was good when the same thermal cycler was used throughout. RAPD proved to be a simple and a rapid method for analysing $C$. diphtheriae and it is a method which can be used as a potential alternative to ribotyping or as a screening technique during outbreak investigations.
\end{abstract}

\section{Introduction}

During the last 50 years the incidence of diphtheria within Western Europe declined dramatically due to the introduction of mass vaccination programmes which commenced in the 1940s. However, despite high levels of vaccination coverage against diphtheria, an ongoing outbreak of diphtheria has affected the Russian Federation since 1990 and the epidemic has spread throughout the 15 newly independent states (NIS) of the former Soviet Union [1, 2]. In 1995, >50000 cases were reported from the WHO European Region and $>35000$ of these cases were from the Russian Federation [3]. In 1996, the number of reported diphtheria cases in the NIS decreased by $54 \%$; however, the WHO still considers the epidemic to be an international emergency [3]. There have also been several reports of cases of diphtheria which have been imported from the former USSR into other western European countries [4, 5]. Diphtheria is also endemic in other parts of the world including Turkey, Bangladesh, Vietnam, Africa and parts of South America $[6,7]$. As international travel increases these foci of epidemicity and endemicity represent potential threats for introduction of toxigenic Corynebacterium

Received 29 June 1998; revised version accepted 24 Aug. 1998.

Corresponding author: Dr A.S. De Zoysa (e-mail: adezoysa@ phls.co.uk). diphtheriae to other countries. Epidemiological and microbiological surveillance is essential in all countries, and the use of molecular typing methodologies is crucial to identify the source of sporadic cases if this is not clear from the epidemiological and clinical data. This has highlighted the importance of the development of rapid techniques for the epidemiological characterisation of $C$. diphtheriae, especially when large numbers of isolates have to be analysed.

Several techniques for molecular typing of $C$. diphtheriae have been developed during recent years. The most widely used are ribotyping, pulsed-field gel electrophoresis (PFGE) and multilocus enzyme electrophoresis (MEE) [8-10]. However, all these methods are relatively laborious and time consuming. DNA fingerprinting by the polymerase chain reaction (PCR) has become a routine procedure in molecular microbiology. In comparison with other genotypic methods, PCR-based methodologies are rapid, simple and relatively cheap to perform. One of the most useful PCR approaches is random amplification of polymorphic DNA (RAPD) analysis [11-14]. RAPD analysis is a technique for rapidly detecting genomic polymorphism $[11,12]$. The method utilises a single short oligonucleotide primer of arbitrary sequence which anneals to the DNA template at low stringency. The products are then resolved electrophoretically to produce patterns characteristic of different types. This study investigated the usefulness of RAPD analysis for the 
differentiation of $C$. diphtheriae isolates from Eastern Europe and neighbouring countries, and determined its advantages and potential disadvantages for molecular typing of $C$. diphtheriae.

\section{Materials and methods}

\section{Bacterial strains}

A selection of $45 \mathrm{C}$. diphtheriae isolates of known origin, biotype, toxigenicity status and ribotype were chosen randomly from the diphtheria collection at the PHLS Streptococcus and Diphtheria Reference Unit at the Central Public Health Laboratory, Colindale, London (Table 1). Twenty-seven strains comprised $C$. diphtheriae isolates that had produced 19 distinct ribotype patterns. These isolates were from Russia, Germany, Romania and Sweden. The remaining 18 isolates were of ribotype D1 (previously designated as G1) of which 10 were isolated in Russia (St Petersburg, Republic of
Carelia, Kaliningrad, Murmansk and Leningrad Oblast regions, Lipetzk and Vladimir regions) and the remaining eight were from Estonia, Finland, Germany, Turkmenistan, Kyrgystan, Kazakhstan and Uzbekistan. The previous nomenclature described by De Zoysa et al. [8] in 1994 has now been revised by the European Laboratory Working Group on Diphtheria. As there was no definitive correlation between ribotype and biotype, the previously used prefixes ' $G$ ' and ' $M$ ' have now been replaced by the prefix ' $D$ ' (diphtheria).

The strains, which were stored in blood glycerol $16 \%$ $\mathrm{v} / \mathrm{v}$ broths at $-20^{\circ} \mathrm{C}$, were recovered by inoculation on to Columbia blood agar (Oxoid) and incubated for $18 \mathrm{~h}$ at $37^{\circ} \mathrm{C}$ before the growth was harvested.

\section{DNA preparation}

Two methods of DNA extraction were applied. A loopful of bacteria grown overnight was suspended in

Table 1. Summary of the 45 C. diphtheriae isolates used in RAPD analysis

\begin{tabular}{|c|c|c|c|c|c|}
\hline Strain no. & Country of isolation* & Biotype & $\operatorname{Tox}^{\dagger}$ & Ribotype & $\begin{array}{l}\text { RAPD } \\
\text { type }\end{array}$ \\
\hline $\mathrm{C} 93 / 46$ & Russia (St Petersburg) & Gravis & + & D1 & Rpl \\
\hline C93/49 & Russia (St Petersburg) & Gravis & + & D1 & Rpl \\
\hline $\mathrm{C} 93 / 65$ & Russia (Murmansk Ob.) & Gravis & + & D1 & Rpl \\
\hline $\mathrm{C} 93 / 81$ & Russia (Murmansk Ob.) & Gravis & + & D1 & $\mathrm{Rp} 1$ \\
\hline C93/90 & Russia (Leningrad Ob) & Gravis & + & D1 & Rpl \\
\hline C93/124 & Russia (Rep. Carelia) & Gravis & + & D1 & Rpl \\
\hline $\mathrm{C} 93 / 129$ & Russia (Kaliningrad Ob.) & Gravis & + & D1 & Rpl \\
\hline $\mathrm{C} 95 / 102$ & Russia (Lipetzk Reg.) & Gravis & + & D1 & Rpl \\
\hline C95/114 & Russia (Lipetzk Reg.) & Gravis & + & D1 & Rp1 \\
\hline $\mathrm{C} 95 / 117$ & Russia (Vladimir Reg.) & Gravis & + & D1 & Rpl \\
\hline C93/105 & Estonia (Tallinn) & Gravis & + & D1 & $\mathrm{Rpl}$ \\
\hline $\mathrm{C} 93 / 103$ & Finland (Tampere) & Gravis & + & D1 & $\mathrm{Rp} 1$ \\
\hline C93/104 & Finland (Uusikavpunki) & Gravis & + & D1 & Rp1 \\
\hline $\mathrm{C} 94 / 65$ & Germany (Dresden) & Gravis & + & D1 & Rpl \\
\hline $\mathrm{C} 95 / 214$ & Turkmenistan & Gravis & + & D1 & $\mathrm{Rp} 1$ \\
\hline $\mathrm{C} 95 / 218$ & Kyrgystan & Gravis & + & D1 & Rp1 \\
\hline C95/228 & Kazakhstan & Gravis & + & D1 & Rpl \\
\hline C95/297 & Uzbekistan & Gravis & + & D1 & Rp1 \\
\hline $\mathrm{C} 95 / 66$ & Russia (Omsk Reg.) & Gravis & + & D2 & $\mathrm{Rp} 2$ \\
\hline $\mathrm{C} 93 / 69$ & Russia (Murmansk Reg.) & Gravis & + & D3 & $\mathrm{Rp} 3$ \\
\hline $\mathrm{C} 95 / 87$ & Russia (Omsk Reg.) & Gravis & + & D3 & Rp3 \\
\hline $\mathrm{C} 93 / 78$ & Russia (Murmansk. Ob.) & Gravis & + & D4 & $\mathrm{Rp} 4$ \\
\hline $\mathrm{C} 93 / 126$ & Russia (Rep. Carelia) & Gravis & + & D4 & $\mathrm{Rp} 4$ \\
\hline C93/143 & Russia (Kaliningrad Ob.) & Gravis & + & D4 & $\mathrm{Rp} 4$ \\
\hline $\mathrm{C} 95 / 70$ & Russia (Omsk Reg.) & Mitis & + & D4 & $\mathrm{Rp} 4$ \\
\hline $\mathrm{C} 95 / 108$ & Russia (Lipetzk Reg.) & Gravis & + & D4 & $\mathrm{Rp} 4$ \\
\hline C93/266 & Russia (St Petersburg) & Gravis & + & D5 & Rp5 \\
\hline $\mathrm{C} 93 / 181$ & Russia (Moscow) & Gravis & + & D6 & Rp6 \\
\hline $\mathrm{C} 95 / 115$ & Russia (Vladimir Reg) & Gravis & + & D6 & Rp6 \\
\hline $\mathrm{C} 93 / 45$ & Russia (St Petersburg) & Mitis & + & D7 & $\mathrm{Rp} 7$ \\
\hline C93/91 & Russia (Leningrad Ob.) & Mitis & + & D7 & $\mathrm{Rp} 7$ \\
\hline C95/63 & Russia (Chelyabinsk Reg.) & Mitis & + & D7 & $\mathrm{Rp} 7$ \\
\hline $\mathrm{C} 93 / 132$ & Russia (Kaliningrad Ob.) & Mitis & + & D8 & Rp8 \\
\hline $\mathrm{C} 93 / 183$ & Russia (Dagestan) & Mitis & - & D9 & $\operatorname{Rp} 9$ \\
\hline $\mathrm{C} 93 / 186$ & Russia (St Petersburg) & Mitis & - & D10 & Rp10 \\
\hline $\mathrm{C} 93 / 274$ & Russia (Vladimir Reg) & Gravis & - & D11 & Rp11 \\
\hline $\mathrm{C} 93 / 277$ & Russia (Moscow) & Gravis & - & D12 & Rp12 \\
\hline C94/68 & Germany (Erlabrunn) & Mitis & - & D13 & Rp13 \\
\hline $\mathrm{C} 94 / 66$ & Germany (Berlin) & Mitis & + & D14 & Rp14 \\
\hline $\mathrm{C} 94 / 69$ & Germany (Erlabrunn) & Gravis & - & D15 & $\operatorname{Rp} 15$ \\
\hline $\mathrm{C} 94 / 72$ & Germany (Greifswald) & Belfanti & - & D16 & Rp16 \\
\hline C94/228 & Sweden & Belfanti & - & D17 & Rp17 \\
\hline $\mathrm{C} 94 / 260$ & Germany & Belfanti & - & D18 & Rp18 \\
\hline $\mathrm{C} 94 / 263$ & Germany & Mitis & - & D19 & Rp19 \\
\hline C94/238 & Romania & Gravis & - & D20 & Rp20 \\
\hline
\end{tabular}

${ }^{*}$ Ob, Oblast; Reg, Region; Rep, Republic. ${ }^{\dagger}$ Toxigenicity status. 
$500 \mu \mathrm{l}$ of sterile distilled water. After boiling the suspension for $15 \mathrm{~min}$, it was centrifuged for $1 \mathrm{~min}$ at $10000 \mathrm{~g}$ and the supernate (crude DNA) was used in the PCR reaction. Alternatively, DNA was extracted as described previously by De Zoysa et al. [8].

\section{Primers}

Six 10-mer primers (designated as primers 1-6) of random sequence, available commercially from Amersham Pharmacia Biotech, were screened for their suitability in generating reproducible fingerprints which allowed for discrimination among $C$. diphtheriae isolates (Table 2).

\section{RAPD analysis}

Ready-To-Go ${ }^{\circledR}$ PCR beads pre-dispensed in $0.5-\mathrm{ml}$ tubes (Amersham Pharmacia Biotech) were used in the PCR reaction. Each bead contains thermostable polymerases (Ampli TAQ ${ }^{\circledR}$ and Stoffel fragment), dNTPs $(0.4 \mathrm{mM}$ each dNTP), BSA $(2.5 \mu \mathrm{g})$ and buffer $(3 \mathrm{mM}$

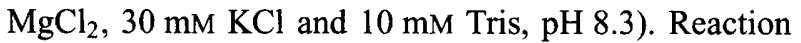
mixtures $(25 \mu \mathrm{l})$ were prepared by adding $35 \mathrm{pmol}$ of primer 2 5'd[GTTTCGCTCC]-3' (Pharmacia Biotech) and $40 \mathrm{ng}$ of template DNA to each tube containing a PCR bead. The reaction mixture was overlaid with mineral oil (Sigma) and cycled through the following temperature profile: $95^{\circ} \mathrm{C}$ for $5 \mathrm{~min}$ followed by 45 cycles at $95^{\circ} \mathrm{C}$ for $1 \mathrm{~min}, 36^{\circ} \mathrm{C}$ for $1 \mathrm{~min}$ and $72^{\circ} \mathrm{C}$ for $2 \mathrm{~min}$. The reaction mixture was held at $4^{\circ} \mathrm{C}$ before electrophoresis of the products. Blank control tubes containing all reagents except the template DNA were also included. All incubations were performed in the same thermal cycler (Biometra, Trio-thermoblock).

Amplified DNA products were electrophoresed on agarose $2 \% \mathrm{w} / \mathrm{v}$ gels (Ultrapure, Life Technologies) in $1 \times$ Tris-borate EDTA buffer $(0.089 \mathrm{M}$ Tris, $0.089 \mathrm{M}$ boric acid, $0.002 \mathrm{M}$ EDTA, $\mathrm{pH} 8.0$ ) and stained in ethidium bromide solution $1.0 \mu \mathrm{g} / \mathrm{ml}$ for $30 \mathrm{~min}$ and photographed under UV transillumination. A 100-bp ladder (Life Technologies) was used as a size marker for the PCR products. RAPD analyses from two different DNA extractions were performed in duplicate for each isolate to assess reproducibility. DNA from a single $C$. diphtheriae isolate of ribotype D1 was amplified in two different thermal cyclers (Biometra Trio-thermoblock and Hybaid Omnigene) to determine any variations.

Table 2. Primers screened in this study

\begin{tabular}{lll}
\hline Primer no. & Sequence & Source \\
\hline 1 & $5^{\prime}-\mathrm{d}[$ GGTGCGGGAA]-3' & Pharmacia \\
2 & $5^{\prime}-\mathrm{d}[$ GTTTCGCTCC]-3' & Pharmacia \\
3 & $5^{\prime}-\mathrm{d}[$ GTAGACCCGT]-3' & Pharmacia \\
4 & $5^{\prime}-\mathrm{d}[$ AAGAGCCCGT]-3'* & Pharmacia \\
5 & $5^{\prime}-\mathrm{d}[$ AACGCGCAAC]-3'* & Pharmacia \\
6 & $5^{\prime}-\mathrm{d}[$ CCCGTCAGCA]-3'* & Pharmacia \\
\hline
\end{tabular}

*See Akopyanz et al. [22].

\section{Biotyping, toxin testing and ribotyping}

All isolates were biotyped and tested for toxigenicity as described by Efstratiou et al. [15]. Ribotyping was performed according to the method described previously [8].

\section{Results}

\section{Optimisation of the RAPD technique}

Preliminary studies were done to develop the optimal conditions for performance of RAPD. RAPD with crude template DNA preparations produced by boiling cell suspensions of the organism resulted in poor amplification of products and poor reproducibility (Fig. 1). This DNA extraction method was, therefore, unsuitable and purified DNA was used throughout the study. After screening the six primers in the RAPD kit (Table 2) the 10-mer primer 5'-d[GTTTCGCTCC]-3' (designated as primer 2) was selected for use. This primer produced clear and definitive RAPD profiles and was the most discriminating.

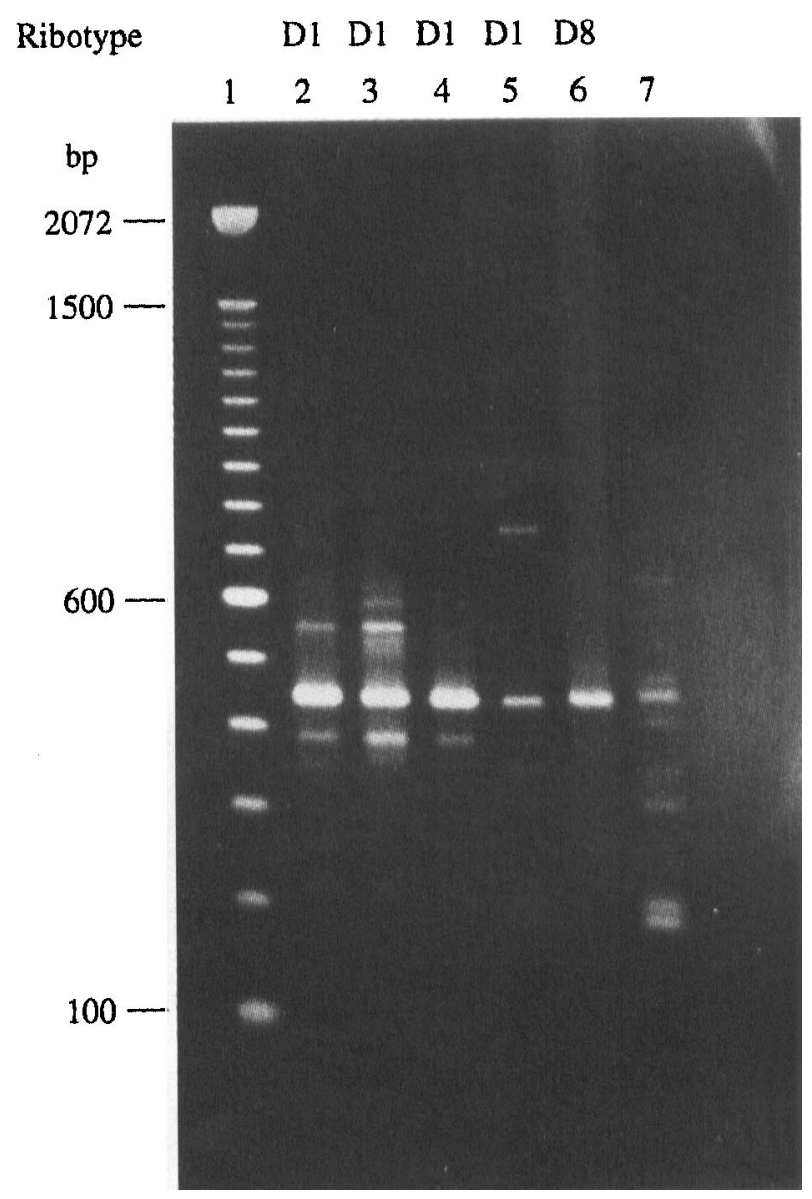

Fig. 1. Effect of using crude template DNA on RAPD typing. Numbered tracks show the profiles obtained for four $C$. diphtheriae strains of ribotype D1 and one strain of ribotype D8 (ribotypes are indicated above the lanes). Lane 1, 100-bp mol. wt standard (sizes are indicated on the left); 2, C95/214; 3, C95/228; 4, C95/114; 5, $\mathrm{C} 93 / 65 ; 6,93 / 132 ; 7$, control tube without template DNA (amplification of products due to natural contamination of Taq $[12,19])$. 
As different concentrations of primer, relative to the DNA template, produced different subsets of bands in a RAPD reaction, the ratio of template DNA to primer in the PCR reaction was optimised by testing a range of DNA concentrations (10-40 ng), by using DNA from a single $C$. diphtheriae isolate with a range of primer 2 concentrations (5-75 pmol) (Fig. 2). The use of low concentrations of DNA resulted in no amplification. High primer concentrations resulted in the amplification of, primarily, low mol. wt bands and low concentrations of primer resulted in a banding pattern composed mainly of high mol.wt bands. Amplification of products was observed in the control samples without DNA when $>50$ pmol of primer were used. For $C$. diphtheriae, $35 \mathrm{pmol}$ of primer to $40 \mathrm{ng}$ of template DNA was optimal for generating good banding patterns without false positives.

Purified DNA samples produced RAPD profiles comprising 10-16 bands for each strain, with sizes ranging from 0.2 to $2.07 \mathrm{~kb}$. RAPD patterns obtained for the $18 \mathrm{C}$. diphtheriae isolates of ribotype D1 (the epidemic ribotype in Eastern Europe) were indistinguishable. These profiles were designated as Rpl. Nineteen RAPD patterns were revealed among the 27 isolates which had produced 19 distinct ribotypes (Fig. $3)$. These profiles were designated Rp2-Rp20. The RAPD profiles were interpreted on the basis of a single band difference. The profiles $\mathrm{Rp} 1, \mathrm{Rp} 4$ and Rp12 were very similar. These profiles were produced by strains of ribotypes D1, D4 and D12, respectively, which differed by a single ribotype band. The RAPD profiles Rp1 and Rp12 differed by a single band and
Rp1 and Rp4 had a two-band difference. The profiles Rp3 and Rp6 were also very similar; there was a three-band difference between Rp3 and Rp6. The other RAPD profiles were distinct from each other. The minor variations in RAPD patterns between Rp1, Rp4 and Rp12, Rp3 and Rp6, which are barely visible in Fig. 3, were not reproducible from run to run and, therefore, only differences in the major bands were used to interpret the results.

\section{Reproducibility}

The reproducibility of the technique was determined by performing duplicate RAPD runs for each isolate with two separate DNA extractions. The results obtained for each isolate were indistinguishable. However, variation within the intensity of some of the amplified bands was observed. Different thermal cycler models (Biometra Trio-thermoblock and Hybaid Omnigene) produced different RAPD profiles when the same DNA sample was used. To assess reproducibility, the thermal cycler (Biometra Triothermoblock) which generated profiles with sharp, definitive fragments was used throughout this study.

\section{Discussion}

The main objective in epidemiological typing of $C$. diphtheriae isolates is to help link cases of diphtheria and to trace outbreaks with greater precision. This information can then be used to locate undisclosed sources of infection and to check that contact tracing has successfully identified all linked cases. Numerous
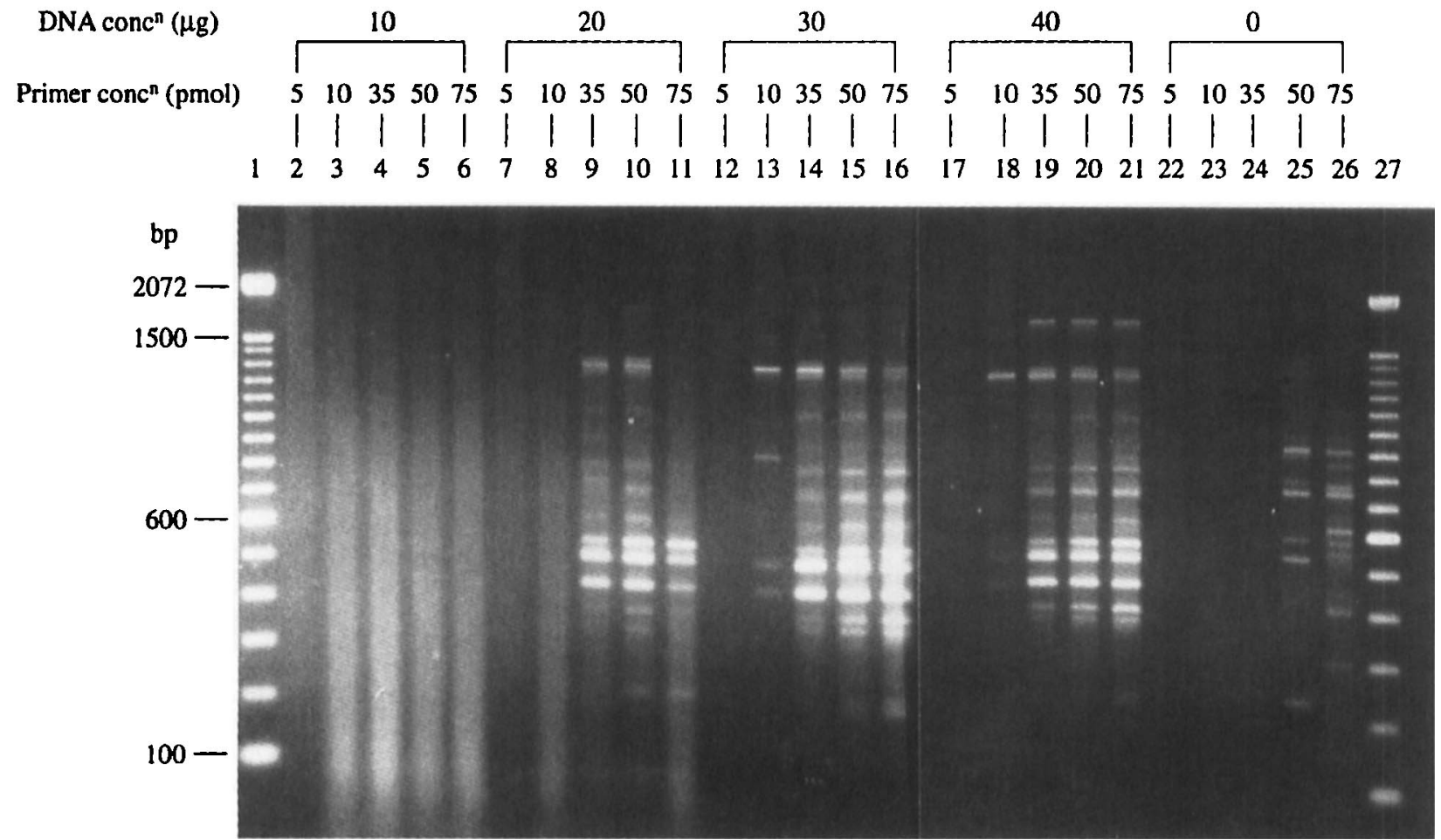

Fig. 2. Optimisation of the template to primer ratio by using varying concentrations of template DNA and primer 2 . Lanes 1, 27, 100-bp mol. wt standard (sizes indicated on the left). The concentration of primer and template DNA used are indicated above each lane. 


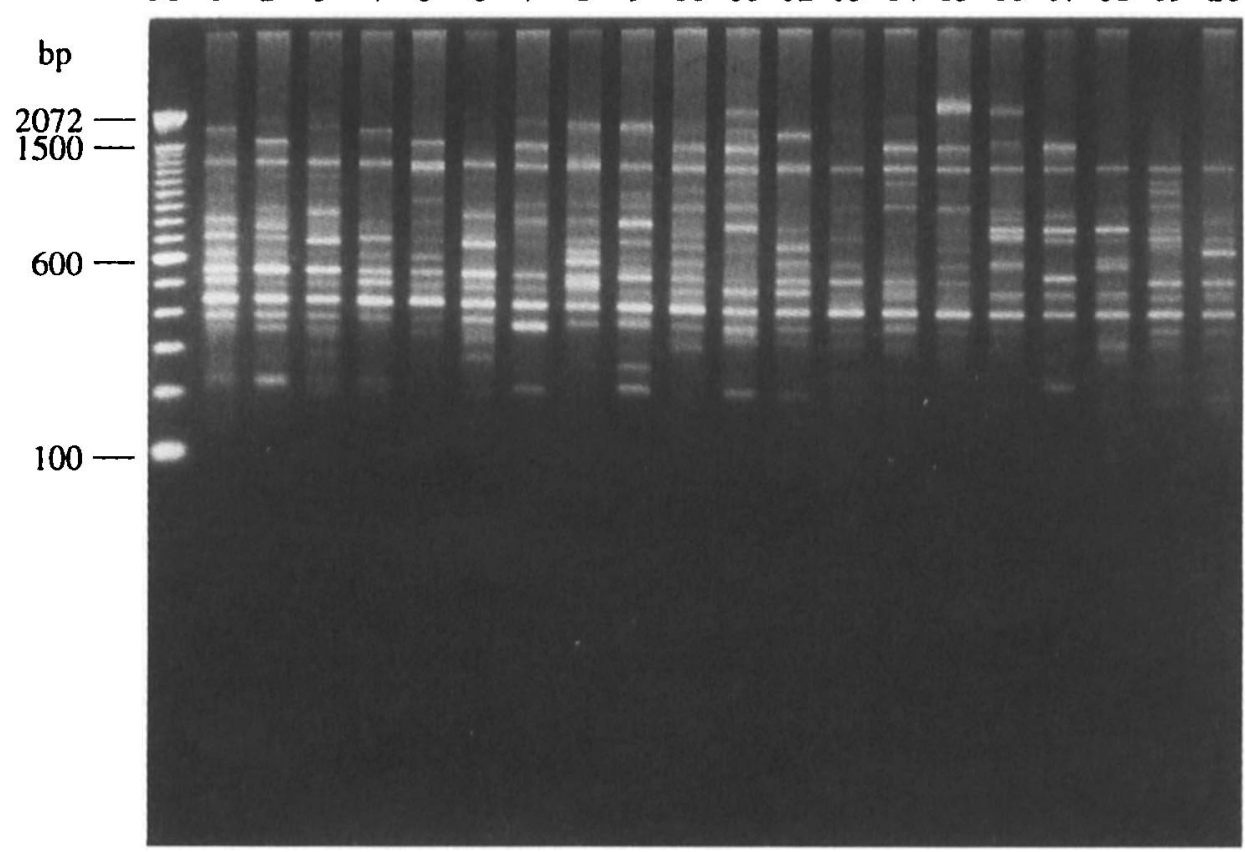

Fig. 3. Representative RAPD profiles of $C$. diphtheriae produced by primer 2 . Lane $M$ shows a 100-bp mol.wt standard. Numbered lanes show the RAPD profiles obtained as follows: 1, C93/46, Rp1; 2, C92/66, Rp2; 3, C93/69, Rp3; 4, C93/78, Rp4; 5, C93/266, Rp5; 6, C93/181, Rp6; 7, C93/45, Rp7; 8, C93/132, Rp8; 9, C93/183, Rp9; 10, C93/186, Rp10; 11, C93/274, Rp11; 12, C93/277, Rp12; 13, C94/68, Rp13; 14, C94/66, Rp 14; 15, C94/69, Rp15; 16, C94/72, Rp16; 17, C94/228, Rp17; 18, C94/260, Rp18; 19, C94/263, Rp19; 20, C94/238, Rp20.

studies have reported the application of molecular typing methods to distinguish between strains of $C$. diphtheriae [8-10]. All these methods are relatively laborious and time consuming. Currently, ribotyping appears to be the 'gold standard' for typing $C$. diphtheriae; it is highly reproducible and provides good discrimination. However, it requires specialised equipment and is not accessible to many laboratories. The present study investigated the usefulness of the PCRbased RAPD fingerprinting technique to differentiate a selection of $C$. diphtheriae isolates from Eastern Europe and neighbouring countries. The technique utilises arbitrary oligonucleotides to prime DNA synthesis at low annealing temperatures and has the advantage of not requiring any specific knowledge of the DNA sequences of the target organism. The main advantage of RAPD over some recent molecular methods is that it is rapid, simple, less labour-intensive, relatively inexpensive, technically feasible for most laboratories and theoretically applicable to any organism.

In this study, $18 C$. diphtheriae isolates of ribotype D1 and 27 isolates that had produced 19 distinct ribotypes were characterised by RAPD. Ribotype D1 was not discriminated further by RAPD and 19 characteristic RAPD profiles designated $\mathrm{Rp} 2-\mathrm{Rp} 20$ were revealed among the 27 isolates that had also produced 19 distinct ribotypes. Therefore, there was excellent correlation between RAPD profiles and ribotypes. The RAPD profiles Rp1, Rp4 and RP12 produced by strains of ribotypes D1, D4 and D12 were very similar. An earlier study reported that ribotypes D1, D4 and D12 could be clonally related, as they differed by only a single band and pulsed-field gel electrophoresis (PFGE) was unable to distinguish between the three ribotypes $[8,16]$. The RAPD results produced in the present study also provide evidence which indicates a potential clonality between these ribotypes. The profile $\mathrm{Rp} 1$ differed from $\mathrm{Rp} 12$ by a single band and from Rp4 by two bands. The RAPD profiles Rp3 and Rp6 were also very similar. These two profiles had a three-band difference. However, the ribotypes and the PFGE profiles of Rp3 and Rp6 were distinguishable. All other RAPD profiles were distinct from each other and their ribotypes and PFGE profiles were also distinct.

Many publications advocate the use of crude template DNA preparations produced from boiled cells, in order to reduce the overall analysis time. Preliminary studies revealed that crude template DNA preparations in RAPD reactions resulted in poor amplification and the patterns obtained were not reproducible. In 1996, Power [17] demonstrated that the use of crude DNA obtained by boiling cultures of isolates produced RAPD profiles that were not reproducible and suggested the following reasons for these observations. Variable quantities of chromosomal and extrachromosomal DNA were produced by boiling and, therefore, it was, difficult to estimate the amount of DNA accurately; furthermore, inhibitors could be present which inhibit the efficiency of DNA polymerase and DNA may be sheared, resulting in different templates.

During PCR optimisation, it was observed that the use 
of high concentrations of primer $(75 \mathrm{pmol})$ with a fairly low concentration of template DNA (20 ng) only amplified fragments between 300 and $800 \mathrm{bp}$ in length. These observations have been reported previously by several workers $[17,18]$, who suggested that the use of high concentrations of primer could result in the primer annealing to less specific target sequences and, also, the primer could insert more frequently into the template causing the generation of only the small fragments. The amplification of artefactual bands in the control samples without DNA has also been reported by William et al. [12]. Böttger in 1990 [19], documented that artefactual bands in control samples probably resulted from 'natural' contamination of the Taq polymerase with bacterial DNA and it was particularly evident when universal primers were used. Many workers $[20,21]$ have also shown that these 'bands' did not affect the resulting RAPD pattern, as none of the bands in the RAPD profile matched the bands in the control tubes. However, in the present study it was observed that some of the bands produced in the control tubes were of similar mol. wts to those in the RAPD profile. For this reason, a primer to template ratio was chosen that did not produce artefactual bands in the control tubes but produced good amplification. Furthermore, Gräser et al. [21] reported in 1993 that the reduction of the number of cycles used in the PCR reaction to 27 cycles led to the disappearance of artefactual bands in the control samples.

Comparison of the results obtained for duplicate RAPD runs performed for each strain showed variations in the intensity of some of the amplified bands, which was probably caused by slight differences in the temperature of the individual wells in the thermal cycler [21]. Variations in RAPD profiles which occurred with different brands of Taq polymerase and different models of thermal cyclers have been demonstrated by several workers $[17,20]$. These variations greatly affect reproducibility between different laboratories. The use of Ready-To-Go ${ }^{\circledR}$ PCR beads decreases the variations associated with different brands of Taq polymerase and also reduces the number of pipetting steps and thus minimises the risk of contamination.

In conclusion, RAPD proved to be a discriminatory and rapid method for analysing $C$. diphtheriae isolates. The technique is, in many respects, easier and faster to perform than ribotyping, PFGE and MEE, and does not require specialised expensive equipment. It is a technique which is accessible to many laboratories that may not have access to expensive equipment and reagents. It can be used as an alternative to ribotyping or it can be used as a screening technique during outbreak investigations before ribotyping, as this would avoid complex ribotyping analyses being undertaken on strains that were clearly unrelated. Reproducibility of the technique between laboratories should not be problematic if the technique is standardised (standard method of DNA preparation, use of the same brand of Taq polymerase and the same thermal cycler). As different RAPD primers produce different RAPD profiles, the discriminatory power of RAPD can be maximised by combining RAPD results obtained with several primers.

\section{References}

1. Galazka AM, Robertson SE, Oblapenko GP. Resurgence of diphtheria. Eur J Epidemiol 1995; 11: 95-105.

2. Hardy IRB, Dittmann S, Sutter RW. Current situation and control strategies for resurgence of diphtheria in newly independent states of the former Soviet Union. Lancet 1996; 347: 1739-1744.

3. Dittmann S. Epidemic diphtheria in the Newly Independent States of the former USSR - situation and lessons learned. Biologicals 1997; 25: 179-186.

4. Diphtheria acquired during a cruise in the Baltic sea. Commun Dis Rep, CDR Weekly 1997; 7: 207.

5. De Zoysa A, Efstratiou A, George RC, Vuopio-Varkila J, Jahkola M, Rikushlin Y. Diphtheria and travel. Lancet 1993; 342: 446.

6. Efstratiou A. Corynebacterium diphtheriae: molecular epidemiology and characterisation studies on epidemic and sporadic isolates. Microecol Ther 1995; 25: 63-71.

7. Efstratiou A, George RC. Microbiology and epidemiology of diphtheria. Rev Med Microbiol 1995; 7: 31-42.

8. De Zoysa A, Efstratiou A, George RC et al. Molecular epidemiology of Corynebacterium diphtheriae from northwestern Russia and surrounding countries studied by using ribotyping and pulsed-field gel electrophoresis. $J$ Clin Microbiol 1995; 33: 1080-1083.

9. Mackay AD, De Zoysa AS, Efstratiou A et al. Molecular epidemiology of non-toxigenic Corynebacterium diphtheriae infections in England and Wales. Proceedings from the PHLS 22nd Annual Scientific Conference, September 1997: p 193 (abstract no. 72).

10. Popovic T, Kombarova SY, Reeves MW et al. Molecular epidemiology of diphtheria in Russia, 1985-1994. J Infect Dis 1996; 174: 1064-1072.

11. Welsh J, McClelland M. Fingerprinting genomes using PCR with arbitrary primers. Nucleic Acids Res 1990; 18: 7213-7218.

12. Williams JGK, Kubelik AR, Livak KJ, Rafalski JA, Tingey SV. DNA polymorphisms amplified by arbitrary primers are useful as genetic markers. Nucleic Acids Res 1990; 18: 6531-6535.

13. Welsh $J$, McClelland $M$. Genomic fingerprinting using arbitrarily primed PCR and a matrix of pairwise combinations of primers. Nucleic Acids Res 1991; 19: 5275-5279.

14. van Belkum A. DNA fingerprinting of medically important microorganisms by use of PCR. Clin Microbiol Rev 1994; 7 : 174-184.

15. Efstratiou A, Maple PAC. WHO manual for the laboratory diagnosis of diphtheria. Copenhagen: The Expanded Programme on Immunisation in the European Region of WHO. 1994. ICP/EPI038 (C).

16. De Zoysa A, Efstratiou A. Molecular typing of Corynebacterium diphtheriae from the European region. Proceedings from the International Meeting on Bacterial Epidemiological Markers, Elsinore, Denmark, 10-12 September, 1997: p 43 (abstract no. S502).

17. Power EGM. RAPD typing in microbiology - a technical review. J Hosp Infect 1996; 34: 247-265.

18. Jutra EM, Miller RM, Pepper IL. Optimisation of arbitrarily primed PCR for the identification of bacterial isolates. $J$ Microbiol Methods 1995; 24: 55-63.

19. Böttger EC. Frequent contamination of Taq polymerase with DNA. Clin Chem 1990; 36: 1258-1259.

20. Meunier JR, Grimont PAD. Factors affecting reproducibility of random amplified polymorphic DNA fingerprinting. Res Microbiol 1993; 144: 373-379.

21. Gräser Y, Meyer W, Halle E, Presber W, Schönian G. Optimisation of a PCR-based assay for fingerprinting microorganisms. Med Microbiol Lett 1993; 2: 379-385.

22. Akopyanz N, Bukanor NO, Westblom TU, Kresovich S, Berg DE. DNA diversity among clinical isolates of Helicobacter pylori detected by PCR-based RAPD fingerprinting. Nucleic Acids Res 1992; 20: 5137-5142. 